\title{
Poliquistosis renal del adulto. Nefrectomía bilateral
}

\author{
Diez-Caballero Alonso F, García-Miralles Reyes F. \\ Servicio Urología Fundación Hospital de Manacor. Palma de Mallorca.
}

Actas Urol Esp. 2007;31(5):573

$\mathrm{P}$ aciente de 53 años diagnosticado de poliquistosis renal del adulto a los 30 años con deterioro progresivo de función renal (en situación de pre-diálisis) con múltiples ingresos, en el ultimo año por infección/hemorragia de los quistes renales. Se realiza RNM (Fig. 1), donde se visualiza la poliquistosis hepatorrenal bilateral con sustitución casi total del parénquima renal por múltiples quistes, alguno de ellos ocupados por material hemático. Se realiza nefrectomía

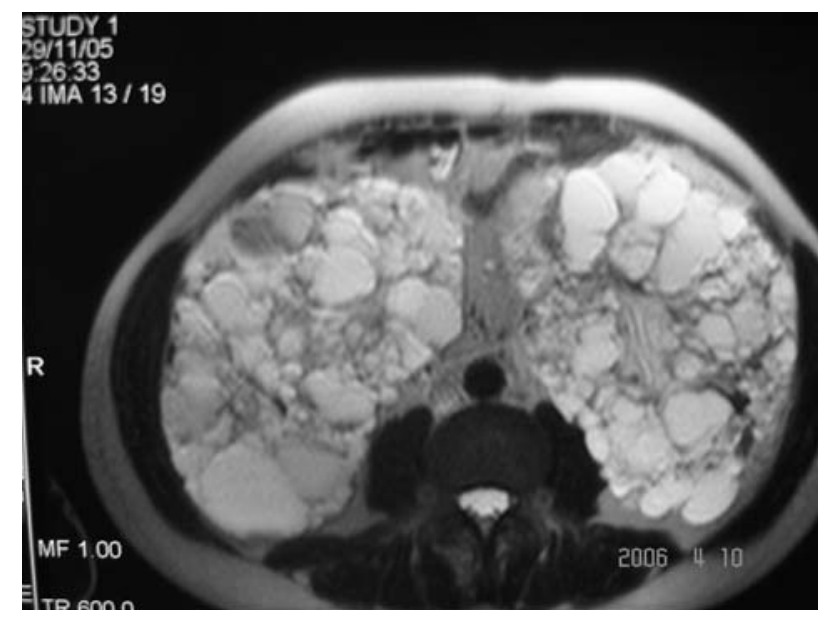

FIGURA 1 bilateral tras abordaje por vía subcostal izquierda ampliada. El estudio anatomopatológico confirma el diagnóstico (Fig. 2).

Correspondencia autor: Dr. F. Díez-Caballero Alonso Servicio de Urología. Fundación Hospital de Manacor. Ctra. Manacor-Alcudia, s/n - 07500 Mallorca (Baleares) Tel.: 971847000

E-mail autor: fdcaballero@yahoo.com Información artículo: Imágenes en urología

Trabajo recibido: mayo 2006

Trabajo aceptado: junio 2006

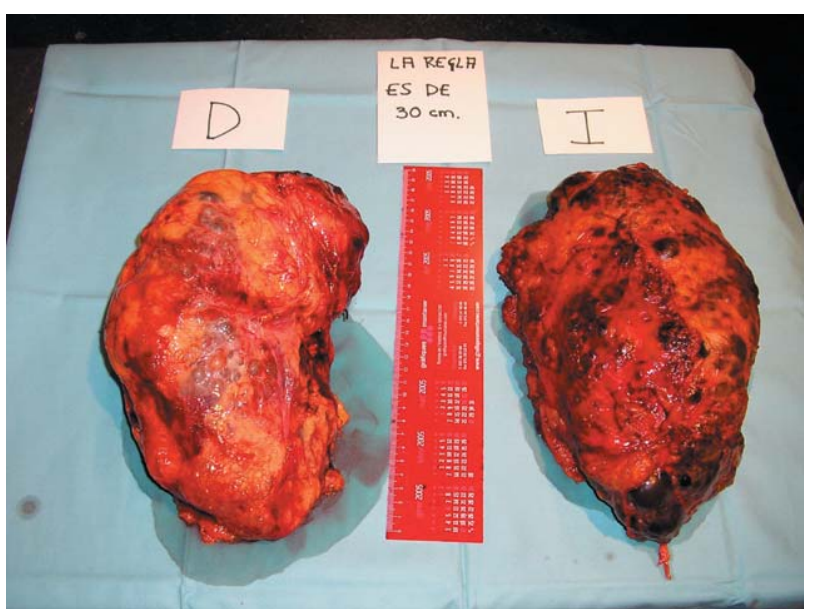

FIGURA 2 